\title{
0435 REDUCING HARM ASSOCIATED WITH WOMEN IN USING COMMERCIAL MOTORCYCLE TRANSPORTATION IN A DEVELOPING COUNTRY
}

D Ojugbana*, K Olebunne, C C Ojugbana, A Okonkwo Correspondence: PATVORA Initiative, No 24 Ojugbana Drive, P.O Box 505, Asaba - Delta State, Nigeria

\subsection{6/ip.2010.029215.435}

Statement of Purpose In Nigeria, dangers posed by commercial motorcyclists at nights are very disturbing. Past studies have shown that a high number of harm incidents involved women, who were robbed, brutalised, raped and killed. The situation is similar for most countries in sub Saharan Africa. The study seeks to address the issue of women vulnerability in commercial motorcycle transportation.

Method Questionnaires and direct interviews were administered to 1200 road users in various locations. Views on causes and suggestions were recorded from passengers of commercial motorcycles, officials of road unions and police. The study lasted 9 months and the data were statistically analysed.

Summary of Results Results showed that $75 \%$ of respondents agreed that motorcycle transportation at nights is unsafe. $68 \%$ affirmed that women are targets. Incidents of rape and abuse were noted. $72 \%$ of women respondents have stopped night movements. Police officials confirmed harassment and attack. $90 \%$ of victims were unable to give description of attackers. Unorganised system of transportation, poor monitoring and inability of the victims to identify attackers hinder progress. The study concludes that actions of unchecked commercial motorcyclists at nights often result in severe consequences for women. The use of motorcycles for commercial transportation between the hours of 19:00 and 06:00 requires additional measures such as data base with verifiable personal information of cyclists. 